\title{
Evidence Based Educational Policy and Practice: The Case of Applying the Educational Effectiveness Knowledge Base ${ }^{1}$
}

\section{Jaap Scheerens}

University of Twente (the Netherlands)

doi: 10.7358/ecps-2014-009-sche

J.Scheerens@utwente.nl

\section{POLITICA E PRATICA EDUCATIVA BASATA SULLE EVIDENZE: IL CASO DELL'APPLICAZIONE DELLE CONOSCENZE BASATE SUI DATI PER L'EFFICACIA EDUCATIVA}

\begin{abstract}
Evidence based educational policy and practice means, first of all, that new programs use relevant scientific knowledge for design purposes, or for critical review of initial program ideas (ex ante evaluation). Secondly, before programs are implemented on a large scale it is considered desirable to conduct smaller scale try-out and pilots, preferably designed as randomized experiments. Third and finally, rigorous ex post or summative evaluation of the implemented program is to be conducted. In this article the first condition is further analysed. It depends on the availability of broadly confirmed relatively stable research outcomes that make sense in a theoretical and practical way. The illustration that is used in this article is the educational effectiveness knowledge base and its application for decision making on school improvement and educational reform. The state of the art on educational effectiveness research provides some guidelines for successful general reform strategies, but also underlines the limits of malleability in education, in the sense that effect sizes of even the most successful strategies tend to be small.
\end{abstract}

Keywords: Educational effectiveness, Evaluation, Evidence based educational, Knowledge base, School policy and practice. 2013.

1 This article is based on two earlier publications from the author: Scheerens, 2011 and 


\section{INTRODUCTION: APPLYING THE EDUCATIONAL EFFECTIVENESS KNOWLEDGE BASE AS AN EXAMPLE} OF EVIDENCE BASED EDUCATIONAL POLICY AND PRACTICE

The quest for evidence based educational policy and practice means, first of all, that new programs use relevant scientific knowledge for design purposes, or for critical review of initial program ideas (ex ante evaluation). Secondly, before programs are implemented on a large scale it is considered desirable to conduct smaller scale try-out and pilots, preferably designed as randomized experiments. Third and finally, rigorous ex post or summative evaluation of the implemented program is to be conducted.

In this article the application of the knowledge base on educational effectiveness will be described as a case of evidence based educational policy and practice. It is seen as relevant to the overall aim of educational policy to enhance the quality of education. The feasibility of an evidence based approach depends on the following premises:

- There is a knowledge base on educational effectiveness.

- Randomized field trials are feasible.

- Evidence based educational reform programs are implementable.

- Core curricula and standards are assessable by means of valid and reliable measurement instruments, of cognitive and sometimes also non-cognitive attainment.

In this article the focus will be on the first point, discussing, within the limits of a brief article, the state of the art in this very broad field, with a specific focus on the school level. Outcomes inform about guidelines and possible strategies for actors at various levels of educational systems, qualify the level of generalization and specificity of the available knowledge and comment on use by different stake holders.

Educational effectiveness is used as the general term including system, school and instructional effectiveness.

When educational systems are seen as hierarchies, school effectiveness can be distinguished from instructional effectiveness, which plays out at classroom level, and from «system effectiveness». The latter term is less common, and refers to a more recent strand of research that is strongly stimulated by the upsurge of international assessment studies. In such studies policy amenable conditions at the national system level can be associated with student outcomes; examples are policies of enhancing school autonomy, accountability and choice. When school effectiveness depends on school level malleable conditions, instructional (or teaching) effectiveness on activities of teachers, and system effectiveness on policy amenable conditions at the national level, the term educational effectiveness can be used as referring to the union of these three. 
At the technical level multi-level analysis has contributed significantly to the development of integrated school effectiveness models. In contributions to the conceptual modeling of school effectiveness, schools became depicted as a set of «nested layers» (Purkey \& Smith, 1983), where the central assumption is that higher organizational levels facilitate effectiveness enhancing conditions at lower levels (Scheerens \& Creemers, 1989).

\section{DEFINITION: SCHOOL EFFECTIVENESS AS A FACET OF SCHOOL QUALITY}

A basic systems model to depict the functioning of educational systems and schools as organizations is a good analytical tool to define facets of quality that are amenable to empirical analysis and verification. According to this model the school is seen as a black box, within which processes or «throughput» take place to transform inputs into outputs. The inclusion of an environmental or context dimension completes the model (see Figure 1).

When the level of outputs is the core of quality judgments on schools, educational programs, or the functioning of national educational systems, this could be described as the productivity perspective. There are many practical applications of this perspective: test based accountability policies, school performance feedback systems, and the comparison of mean country level achievement among countries, on the basis of international assessment studies, like TIMSS and PISA.

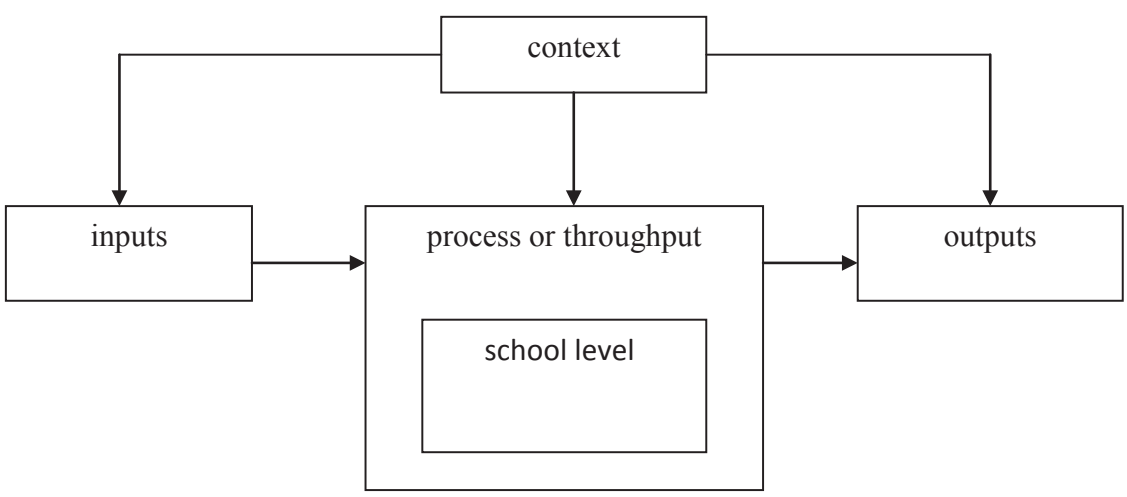

Figure 1. - A basic systems model of school functioning. 
In case the interest is not focused primarily on average achievement levels, but rather on the distribution of outcomes, inputs and processes, equity is the predominant quality facet. In international comparisons equity is getting more and more attention: see for example the OECD Report titled Overcoming social background, based on the 2009 edition of PISA (OECD, 2010). At the school level Inspection Frameworks may contain indicators on equity (Janssens, 2007). When effectiveness is the predominant quality perspective, the focus is on the instrumental value of input and process indicators to maximize output. This is the question on "what works best». From a quality perspective this means that it is not the «beauty» of organizational arrangements or teaching strategies, but the extra value these approaches create in terms of school output. When effectiveness at the lowest possible costs is considered efficiency is the quality facet in question. Monetary measures of inputs are key aspects in efficiency measurements. Finally, the relationship of the school with its environment or context may be the core issue for quality judgments; particularly the question of responsiveness, which in the most general sense means that a school pays attention to impulses from the larger context. Where effectiveness and efficiency deal with the question of "doing things right", responsiveness may be seen to address the question of «doing the right things", such as choosing educational objectives that confirm to the demands of further education or the labor market.

These facets of educational quality, defined on the basis of their key elements and interrelationships included in Figure 1, are schematically summarized below (Table 1). Two final remarks with respect to effectiveness as a facet of school quality are in order. Firstly, it should be noted that effectiveness refers to causality between means and ends in a complex practical situation, and therefore is analytically difficult. Secondly, this very characteristic of being centered on malleable "causes» of intended effects also points at great practical relevance, namely its potential for school improvement.

Table 1.

\begin{tabular}{ll}
\hline QUALITY FACET & KEY INDICATORS AND RELATIONSHIP BETWEEN INDICATORS \\
\hline Productivity & Outcomes \\
Equity & $\begin{array}{l}\text { The distribution of inputs, processes and outcomes } \\
\text { Association between inputs and processes on the one hand } \\
\text { and outcomes on the other }\end{array}$ \\
Efficiency & $\begin{array}{l}\text { Effectiveness at the lowest possible costs } \\
\text { The way input, processes and intended outcomes are fitted } \\
\text { Responsiveness }\end{array}$ \\
\end{tabular}




\section{RESEARCH EVIDENCE: RESULTS FROM REVIEWS AND META-ANALYSES}

\subsection{Qualitative review: fair consensus on the factors that matter}

In three recent «State of the art» review studies by Reynolds et al. (2013), Muijs et al. (2013) and Hopkins et al. (2013) an overview is given of the most relevant factors in three respective sub-fields: Education Effectiveness Research (EER), Teaching Effectiveness research (TE), and School and System Improvement (SSI). A summary is provided in Table 2.

Once again there is a fair consistency in the factors that are mentioned in the three more contemporary reviews, for examples with respect to core factors like: academic emphasis, time and opportunity, structuring and scaffolding, leadership and monitoring. Moreover, most of these factors also appear in earlier reviews. In the more recent reviews there is more differentiation and emphasis on classroom level instructional variables, both from the tradition of structured teaching and direct instruction and from more constructivist orientations (importance of prior knowledge, self regulated learning and teaching meta-cognitive strategies).

Table 2. - Effectiveness enhancing conditions referred to in the review studies by Reynolds et al. (2013), Muijs et al. (2013) and Hopkins et al. (2013), cited from Scheerens, 20136.

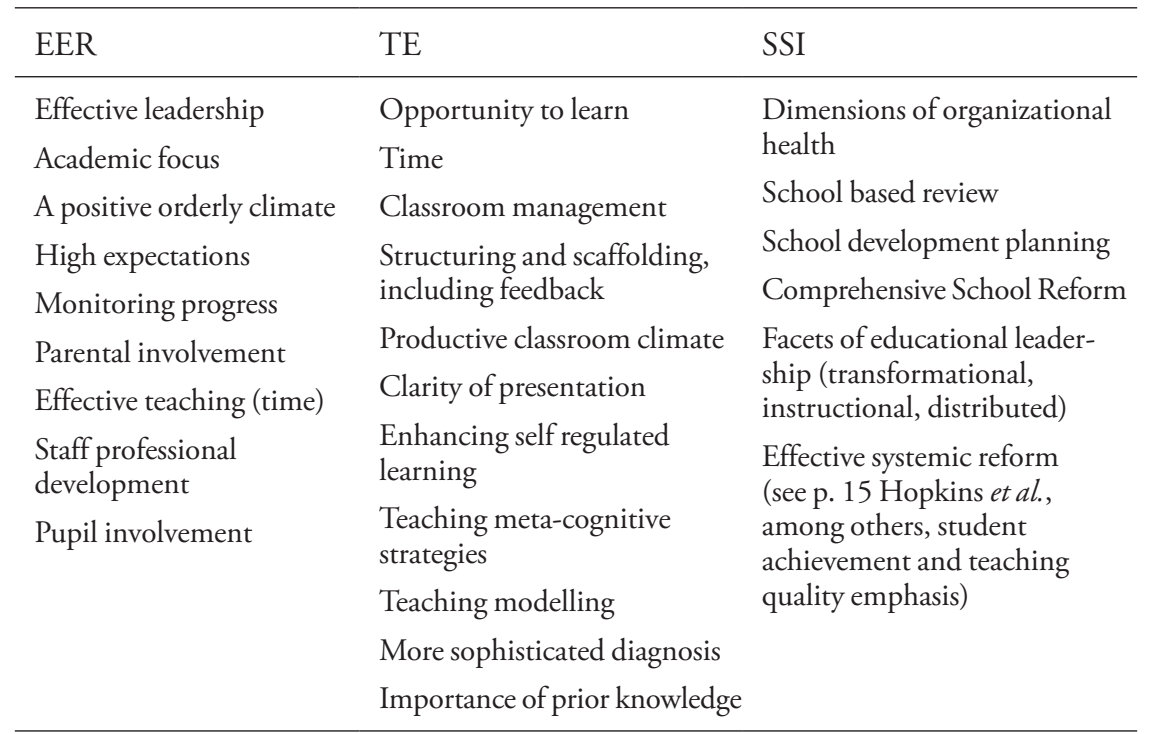


From this consistency among review studies it might be concluded that school and educational effectiveness research have an established knowledge base. However, two notes of dissonance are to be considered. Firstly, behind this consensus on general characteristics hides considerable divergence in the actual operationalization of each of the conditions. Evidently concepts like "productive, achievement-oriented climate» and "educational leadership» are complex concepts and individual studies tend to vary in the focus that different elements receive.

Scheerens and Bosker (1997, ch. 4) provide an analysis of the meaning of the factors that are considered to work in schooling, as apparent from the questionnaires and scales as used in the actual empirical school effectiveness studies. This work has been taken to a further level of detail by Scheerens et al., 2007.

\subsection{Quantitative effects; less consensus about the size of effects}

Unlike the agreement on the most important variables in school effectiveness research, reviews of the effect sizes, in the sense of the estimate of the association between a specific factor and educational achievement, show far less consensus. This state of affairs will be elaborated in subsequent sections.

Meta-analyses compute average effect sizes across individual research studies addressing the association of a certain independent variable and educational achievement. Various coefficients may be used for the estimates. The standardized mean difference (between a treatment and a control group), coefficient $d$, and certain correlation coefficients (r), are the most common.

Hattie (2009) provides massive quantitative evidence on the association of numerous school, teacher and teaching variables with student achievement. Average effect sizes for school, curriculum, teacher and teaching factors in terms of the $\mathrm{d}$ coefficient (standardized difference between means) reported by Hattie are $.23, .45, .49$ and .43 respectively (ivi, pp. 74, 109, 130, 162 and 201). According to Cohen (1977), effect sizes of .2 are considered small, .5 medium and .8 large. When applying these standards the average effect sizes should be considered as slightly below medium. Still, meta-analyses that are carried out by European authors show effect sizes that are even lower; see for example Witziers et al., 2003; Scheerens et al., 2007; Seidel \& Shavelson, 2007; Creemers \& Kyriakides, 2008. By way of illustration some of the results on key variables listed in the three state of the art papers, educational leadership, evaluation and monitoring, learning time, structured teaching and quantity of teaching are compared. 
Table 3. - Results from recent meta-analyses (coefficients are based on the Fisher $Z$ transformation of correlations; as Hattie presents effect sizes in terms of $d$, these are indicated in italic).

Weighing the evidence from meta-analyses.

School level variables

\begin{tabular}{lccc}
\hline & $\begin{array}{c}\text { Scheerens et al. }, \\
2007\end{array}$ & $\begin{array}{c}\text { Hattie, } \\
2009\end{array}$ & $\begin{array}{c}\text { Creemers \& Kyriakides, } \\
2008\end{array}$ \\
\hline Consensus \& cohesion & .02 & - & .16 \\
Orderly climate & .13 & .34 & .12 \\
Monitoring \& evaluation & .06 & .64 & .18 \\
Curriculum/OTL & .15 & - & .15 \\
Homework & .07 & .30 & - \\
Effective learning time & .15 & .34 & - \\
Parental involvement & .09 & .50 & - \\
Achievement orientation & .14 & - & .07 \\
Educational leadership & .05 & .36 & - \\
Differentiation & .02 & .18 & - \\
\hline
\end{tabular}

Teaching level variables

\begin{tabular}{lccc}
\hline & $\begin{array}{c}\text { Scheerens et al., } \\
2007\end{array}$ & $\begin{array}{c}\text { Hattie, } \\
2009\end{array}$ & $\begin{array}{c}\text { Seidel \& Shavelson, } \\
2007\end{array}$ \\
\hline Time and OTL & .08 & .34 & .03 \\
Classroom management & .10 & .52 & .00 \\
Structured teaching & .09 & .60 & .02 \\
Teaching learning strategies & .22 & .70 & .22 \\
Feedback \& monitoring & .07 & .66 & .01 \\
\hline
\end{tabular}

School effectiveness research is mostly field research. From the perspective of applicability, this can be seen as an advantage. Another way to express this would be to say that school effectiveness research will tend to have high ecological validity. the key independent variables in school effectiveness research was already mentioned, and underlined by pointing at the malleable nature. Referring again to the knowledge base on educational and school effectiveness, the question "what works best in schooling» could be answered by (a) considering the set of factors on which a fair consensus among reviewers exists, and (b) by rank ordering these variables according to the average effect size reported in meta-analyses. Any attempt at this 
kind of synthesis should be seen as tentative, because of the noted variation in effect sizes across meta-analyses, and the fact that it is not possible to capture a moving target, as new results are continuously added to the knowledge base. Nevertheless an attempt at such a tentative synthesis will be made by putting together main results from Marzano, 2003, Scheerens et al., 2007 and Hattie, 2009 (see Table 4). The results that Marsano presents depend to a large extent on a meta-analysis by Scheerens \& Bosker, 1997. Hattie's results are based on syntheses of numerous meta-analyses for each variable. In a few cases, there was not a straightforward match with variables that were included in Hattie's synthesis of meta-analyses, and somewhat specific operationalizations were chosen; these are marked and explained in the legenda of the table. The variables mentioned in the overview by Marzano are taken as the starting point, and rank-ordered from high to low in their association with student achievement. In the fourth column of the table the average of the three coefficients for each variable are shown. It appears that the original rank ordering by Marzano is preserved in the averages. The effect sizes are rendered in terms of the $\mathrm{d}$ coefficient.

Of course the labels of the variables are quite general. At the same time even the general labels provide a relatively clear idea on what aspects of school functioning should be optimized in order to enhance student performance. Opportunity to learn basically refers to a good match between what is tested or assessed in examinations and the content that is actually taught.

Table 4. - Rank ordering of school effectiveness variables according to the average effect sizes (d coefficient) reported in three reviews/meta-analyses;

(*) operationalized as "enrichment programmes for gifted children»;

$\left.{ }^{* *}\right)$ operationalized as "teacher expectations»; (**) operationalized as "team teaching».

\begin{tabular}{lcccc}
\hline & $\begin{array}{c}\text { Marzano, } \\
2003\end{array}$ & $\begin{array}{c}\text { Scheerens et al., } \\
2007\end{array}$ & $\begin{array}{c}\text { Hattie, } \\
2009\end{array}$ & $\begin{array}{c}\text { Average } \\
\text { effect size }\end{array}$ \\
\hline Opportunity to learn & .88 & .30 & $.39^{*}$ & .523 \\
Instruction time & .39 & .30 & .38 & .357 \\
Monitoring & .30 & .12 & .64 & .353 \\
Achievement pressure & .27 & .28 & $.43^{* *}$ & .327 \\
Parental involvement & .26 & .18 & .50 & .313 \\
School climate & .22 & .26 & .34 & .273 \\
School leadership & .10 & .10 & .36 & .187 \\
Cooperation & .06 & .04 & $.18^{* * *}$ & .093 \\
\hline
\end{tabular}


Instruction time may be expressed in a more global sense as officially available or allocated learning time or more specifically as «time on task», or «academic learning time». Monitoring may include various types of school based evaluations, like school based review, school performance feedback, or school aggregate measures of formative assessment at classroom level. Parental involvement might mean the actual involvement of parents with school matters, or the policies by the school to encourage parents to be involved. Achievement pressure refers to school policies and practices that make use of achievement results and performance records, but also to more climate like and attitudinal facets of fostering high expectations of student performance. School climate generally refers to good interpersonal relations at school, but often more specifically to «disciplinary climate» and the fostering of an ordered and safe learning environment.

On school leadership many specific connotations are used. Instructional leadership appears to be the most frequently used and successful interpretation in this literature. Cooperation in general terms, often measured with proxy's like the number of staff meetings, usually has a relatively weak to negligent association with student performance. Only when cooperation is explicitly task and result oriented somewhat larger effect sizes are found (cfr. Lomos et al., 2011). When the rank ordering of these results is further contemplated it appears that curriculum variables (opportunity to learn and learning time) predominate. Monitoring could be seen as part of this curricular "syndrome», but could also be seen as a broader performance lever, which might include teacher appraisal, and schools being part of accountability schemes.

The first four highest ranking factors are all to do with a focus of the primary process of teaching and learning at school. The lowest four factors are organizational measures, or «secondary processes». In the school improvement literature variables like staff cooperation and school leadership are overrated for their importance, when one considers the quantitative evidence on performance effects. An orderly school climate is more like an organizational condition that is directly supportive of the primary process, in the sense that it is about creating a safe and productive learning atmosphere.

\subsection{Effective teaching and effective teachers in effective schools}

Effective schooling is, too a large extent, providing support at school level for optimizing teaching at classroom and individual student level. A good overview of the most relevant variables in teaching effectiveness is provided in Table 5, cited from Brophy, 2001. 
Table 5. - Variables in effective teaching, from Brophy, 2001.

Opportunity to learn

Curricular alignment

Supportive classroom climate

Achievement expectations

Cooperative learning

Goal-oriented assessment

Coherent content; clear explanations

Thoughtful discourse

Establishing learning orientations

Sufficient opportunities for practice and application

Scaffolding student's task engagement

Modelling learning and self-regulation strategies

Good, Wiley, \& Florence, 2009 refer to three latent teaching factors: structure and classroom management, supportive climate and cognitive activation. The integration of these ideas and Brophy's overview of teaching variables is shown in Table 6, based on Klieme, 2012.

Table 6. - Latent and manifest teaching variables, adapted from Klieme, 2012.

STRUCTURE AND CLASSROOM MANAGEMENT

Opportunity to learn

Available time

Degree of student involvement

Curriculum alignment

Visible and coherent planning

Goal oriented assessment

Focus on what is important

\section{SupPORTIVE CLASSROOM CLIMATE}

Pro-active and supportive classrooms

Caring communities

Appropriate expectations

Help students to exceed

\section{Cognitive aCtivation}

Coherent content

Sufficient depth

Thoughtful discourse

Scaffolding students' ideas and task involvement

Understanding at a higher level

Authentic application of concepts in different contexts 


\section{APpliCATION: STRATEgies FOR IMPROVING SCHOOL EFFECTIVENESS}

\subsection{The substantive focus of school level strategies}

The school and educational effectiveness knowledge base provide an instrumental orientation to school improvement, meaning that enhancing identified school factors is expected to lead to better student performance. In very broad terms the variables identified in educational effectiveness have to do with the technology of the curriculum (as intended and implemented) and with facets of the organizational climate. In this way one could say that a first broad orientation to school improvement could be labelled as the technology and climate emphasis.

However, it should be noted that schools can choose alternative orientations. A second strategy might be labelled the teacher recruitment and professional development strategy. According to this strategy most of a school's energy to improve should be focussed at teacher issues, including human resources management. In the third place schools could capitalize on matching and grouping issues. Matching could be both externally oriented, towards the local community, towards higher administrative levels, other schools and to parents, and internally oriented in grouping of students in classrooms and learning groups and assigning teachers to these groups of students.

As noted in the above, applying the knowledge base of educational effectiveness research is closest to the Technology and Climate orientation. The general factors that have been discussed and rank-ordered in previous sections are all candidates to be stimulated. More minute and detailed descriptions of these variables are available in the literature, e.g. Marzano, 2003, Scheerens et al., 2007 and Hattie \& Alderman, 2012. On the level of strategy choice a more synthetic description of the key factors is considered helpful. The following alternative emphases within the Technology and Climate orientation are distinguished:

a. Exposure to educational content. This could be seen as a composite of opportunity to learn and instruction time. It expresses the curricular focus and duration of exposure in school curricula and teaching.

b. Evaluation, monitoring and feedback provisions. Evaluation and feedback can be seen as driving improvement at school and classroom level. Implied facets are clarity of purpose through standards, examination syllabi etc., verification of what students have learned, identification of strengths and weaknesses in content and skills that are mastered, feeding back and diagnosis of outcome patterns, systematic consideration of remedial strategies 
and setting concrete goals for improvement at student, classroom and school level, in cooperation with other teachers, school principals and eventual support staff. This latter characteristic could make evaluation/ feedback/systematic corrective action the core of task related professional development and teacher cooperation.

c. Managing the school climate. This involves diverse facets like creating a safe atmosphere, positive interactions, as well as fostering high expectations and pressure to achieve.

d. Managing the teaching and learning program. Repeated studies, in which more behaviouristic approaches like «direct teaching» were compared to constructivist approaches and where no significant differences in student achievement were found, have inspired analysts to propose more general underlying constructs. One example is the construct of «cognitive activation" (Klieme, 2012), discussed earlier. Another example is the term «focused teaching» coined by Louis Hattie et al. (2009) proposes «active teaching» as an overall construct. Careful attention to lesson planning, variation in structure and independence in learning assignments and keeping students engaged seem to be the core issues in these constructs.

e. Meta-control as the overriding leadership approach. Meta-control is a concept from control theory, and literary means "control of controllers". Applied to school leadership this concept emphasizes the notion that schools are professional organizations, with teachers as semi-autonomous professionals. Teachers may be metaphorically seen as the prime «managers» of teaching and learning at school. A school leader as a meta-controller is not a laissez-faire leader, but one who sets clear targets, facilitates, and monitors the primary process of schooling from a distance (Scheerens, 2012).

These five strategic angles to the substantive focus of enhancing school effectiveness can be seen as having certain connections. Exposure and evaluation/feedback have a common element in educational objectives and learning standards. Alignment of what is taught and what is tested is the key issue of opportunity to learn. High expectations and pressure to achieve, as facets of the school climate, likewise need a substantive focus in the form of objectives, standards, assessment instruments and feedback. The educational content dimension, perhaps indicated as the implemented school curriculum, is a core dimension of the teaching and learning programme, next to the ideas on transmission that are more central in concepts like cognitive activation. Managing all of these strategies, as well as their connections, is the task of school leadership as meta-control. Integration of these angles to school improvement, inspired by the educational knowledge base is very close to the approach of Comprehensive School Reform, e.g. Borman et al. (2003). 


\subsection{How system level policies could foster these school level strategies}

System level policies and structural characteristics of educational system can be seen as pre-conditions or constraints of school level improvement policies, to which schools need to adapt. More analytically one could ask which system level conditions could be seen as supportive of effective schools and effective school improvement. A third, more «neutral» approach might be to just establish where there are matches between the major system level reform dimensions and structural conditions, as discussed earlier, and the school level improvement strategies.

Following this third approach would favour accountability policies as the best matching system level arrangement for the Technology and Climate orientation to effective school improvement. Accountability policies touch directly on core facets of school functioning, like performance standards, achievement orientation, and perhaps also on the "internal accountability» of schools (see Carnoy et al., 2003). As accountability policies are almost inevitably associated with a degree of centrality in the curriculum, this would emphasize the connection with content exposure and opportunity to learn at school level.

Other system level policies and structural arrangements are more closely associated with alternative orientations. Enhanced school autonomy, as well as strong teacher policies appeal more to teacher recruitment and professional development. Choice and market mechanisms, as well as tracked versus comprehensive school systems, are more associated with admittance, selection and grouping processes at school level.

\section{CONCLUSION: CONSTRAINTS OF THE EVIDENCE BASED APPROACH AND HOW TO OVERCOME THEM}

Use and application of scientific knowledge in public policy making and public service has been studied since decades in the field of using results from program evaluations (e.g. Weiss, 1980). It is evident from this literature that in actual practice it is very difficult to align scientific rationality with "political rationality». Politicians and planning officers are likely to have broader agenda's and additional interests over a straightforward «instrumental use» of scientific knowledge even if it is closely geared to a practical issue, as in evaluation research. Besides, the "demand side» may not be organized in a way that research findings are easily absorbed. Some authors (e.g. Caplan et al., 1975) emphasized the importance of knowledge brokerage roles in this 
context. A quite practical aspect of this lack of alignment between research and policy is the issue of timing. In many cases policy planners do not seem to be able to preserve the time to study relevant research evidence, carry out ex ante evaluations or pilot studies, before launching new policy ideas and programs.

Secondly, autonomy may clash with the "rules of the game» of strong research designs. Particularly in those education systems where schools and teachers are highly autonomous, the rigorous norms of applying randomized field trials and summative evaluation designs are likely to be very hard to implement (Scheerens \& Doolaard, 2013).

But critical questions need also to be asked about the supply side. As the case of the educational effectiveness knowledge base shows, particularly as far as the results of meta-analyses are concerned, outcomes are contested, the research input is vast and dynamic, and "useability" is not the first concern of academic research, despite of the growing importance of clearing houses.

Finally, I discern a discrepancy between the high strung expectations of educational reform (e.g. OECD, 2010: The high costs of low performance) and the modesty of effect sizes in educational effectiveness research. Research findings underline stability, resilience of educational systems against change and plurifinality, which means that different treatments in education often have very similar effects. In short, apart from a very limited number of robust outcomes, the state of the art of educational effectiveness, in my opinion, underlines the message that malleability is limited, and this goes very much against the current reformist ideology.

As far as overcoming these constraints are concerned there are no easy answers. As far as optimizing research designs are concerned, capitalizing on naturally occurring variance and "experiments of nature» will often be the highest obtainable approaches. The linkage between research and educational policy and practice is likely to remain a negotiated order, where research outcomes "affect in ripples and not in waves" (Patton, 1978). Substantively the combination of optimizing opportunity to learn and application of evaluation and data feedback is the most promising mechanism for improvement. A new concern for efficiency is called for in reform policies and school improvement, where act is taken of the limits of malleability of educational systems. 


\section{REFERENCES}

Borman, G. D., Hewes, G. M., Overman, L. T., \& Brown, S. (2003). Comprehensive school reform and achievement: A meta-analysis. Review of Educational Research, 73, 125-230.

Brophy, J. (2001). Generic aspects of effective teaching. In M. C. Wang \& H. J. Walberg, Tomorrow's teachers. Richmond, CA: McCutchan Publishing Company.

Caplan, N., Morrison, A., \& Stambaugh, R. (1975). The use of social science knowledge in policy decisions at the national level. Ann Arbor, MI: University of Michigan - Institute for Social Researh.

Carnoy, M., Elmore, R., \& Siskin, L. S. (2003). The new accountability. High schools and high stakes testing. New York: Routledge.

Cohen, J. (1977). Statistical power analysis for the behavioral sciences. New York: Academic Press.

Creemers, B. P. M., \& Kyriakides, L. (2008). The dynamics of educational effectiveness. London - New York: Routledge.

Good, W., \& Florez, I. R. (2009). Effective teaching: An emerging synthesis. In G. Dworkin (Ed.), International handbook of research on teachers and teaching (pp. 803-816). New York: Springer.

Hattie, J. (2009). Visible learning. Abingdon: Routledge.

Hattie, J., \& Alderman, E. M. (Eds.). (2012). International guide to student achievement. London - New York: Routledge.

Hopkins, D., Stringfield, S., Harries, A., Stoll, L., \& Mackay, T. (2013). School and system improvement. School Effectiveness and School Improvement, 24.

Janssens, F. J. G. (2007). Supervising the quality of education. In W. Böttcher \& H. G. Kotthoff (Hg.), Schulinspektion: Evaluation, Rechenschaftslegung und Qualitätsentwicklung. Münster: Waxmann.

Klieme, E. (2012). Qualities and effects of teaching. Towards a conceptual theory of teaching, Key note address of EARLI SIG Meeting Educational effectiveness, Zürich, 23 August.

Lomos, C., Hofland, R., \& Bosker, R. (2011). Professional communities and learning achievement - A meta-analysis. School Effectiveness and School Improvement, 22, 121-148.

Louis, K.S., Dretzke, B., \& Wahlstrom, K. (2010). How does leadership affect student achievement? Results from a national US survey. School Effectiveness and School Improvement, 21(3), 315-336.

Marzano, R. J. (2003). What works in schools. Translating research into action. Alexandria, VA: Association for Supervision and Curriculum Development.

Muijs, D., Creemers, B., Kyriakides, L., van der Werf, G., Timperley, H., \& Earl, L. (2013). Teaching effectiveness. A state of the art review. School Effectiveness and School Improvement, 24. 
Patton, M. Q. (1978). Utilization focused evaluation. Beverly-Hills, CA: Sage.

Purkey, S. C., \& Smith, M. S. (1983). Effective schools: A review. The Elementary School Journal, 83, 427-452.

Reynolds, D., Sammons, P., De Fraine, B., Townsend, T., van Damme, J., Teddlie, C., \& Stringfield, S. (2013). Educational Effectiveness Research (EER): A state of the art review. School Effectiveness and School Improvement, 24.

Scheerens, J. (Ed.). (2012). School leadership effects revisited. Review and meta-analysis of empirical studies. Dordrecht - Heidelberg - London - New York: Springer.

Scheerens, J. (2013a). What is effective schooling. Paper for the International Baccalaureate Organization, Washington, DC. http://www.ibo.org/research/resources.

Scheerens, J. (2013b). The ripples and waves of educational effectiveness research: Some comments to "Getting lost in translation». School Leadership and Management, 33(1), 20-25.

Scheerens, J., \& Bosker, R. J. (1997). The foundations of educational effectiveness. Oxford: Elsevier Science Ltd.

Scheerens, J., \& Creemers, B. P. M. (1989). Conceptualizing school effectiveness. International Journal of Educational Research, Special Issue: Development in school effectiveness research, 13(7).

Scheerens, J., \& Doolaard, S. (2013). Review studie "Onderwijskwaliteit PO». Review Study "Educational Quality».

Scheerens, J., Luyten, H., Steen, R., \& Luyten-de Thouars, Y. (2007). Review and meta-analyses of school and teaching effectiveness. Enschede: University of Twente (the Netherlands), Department of Educational Organisation and Management.

Scheerens, J., Luyten, H., \& van Ravens, J. (2011). Perspectives on educational quality. Illustrative outcomes on primary and secondary education in the Netherlands. Research Briefs. Dordrecht - Heidelberg - London - New York: Springer.

Seidel, T., \& Shavelson, R. J. (2007). Teaching effectiveness research in the past decade: The role of theory and research design in disentangling meta-analysis results. Review of Educational Research, 77(4), 454-499.

Weiss, C. H. (1980). Knowledge creep and decision accretion. Knowledge, Creation, Diffusion, Utilization, 1(3).

Witziers, B., Bosker, R. J., \& Krüger, M. L. (2003). Educational leadership and student achievement: The elusive search for an association. Educational Administration Quarterly, 39(3), 398-425. 


\section{RiassunTO}

In campo educativo, basare le politiche e le pratiche sulle evidenze significa fare in modo che l'elaborazione dei nuovi programmi risponda a tre condizioni: prima di tutto è necessario utilizzare conoscenze scientifiche rilevanti per la progettazione o per la revisione critica delle idee iniziali (valutazione ex ante); in secondo luogo, prima che i programmi siano attuati su larga scala, è opportuno condurre, su scala ridotta, "try-out» e studi pilota, progettati preferibilmente come esperimenti randomizzati; infine è necessario effettuare un rigoroso studio ex post (valutazione finale) del programma attuato. In questo articolo è analizzata, in particolare, la prima delle condizioni sopra descritte. Questa scelta dipende dalla necessità di ottenere risultati di ricerca relativamente stabili e che abbiano senso a livello teorico e pratico. Il percorso che si segue in questo articolo, consiste nell'illustrare la conoscenza basata sui dati, e la messa in atto di interventi educativi efficaci, nell'ottica di assumere decisioni utili per il miglioramento della scuola e delle riforme scolastiche. Lo stato dell'arte nella ricerca sull'educazione efficace fornisce alcune linee guida per conseguire, generalmente, il successo di strategie didattiche riformate, ma sottolinea anche i limiti della possibilità di plasmare la "materia educativa», nel senso che le ricadute concrete, anche delle strategie di maggior successo, tendono ad essere di piccole dimensioni.

Parole chiave: Conoscenza basata sui dati, Educazione basata sull'evidenza, Efficacia educativa, Monitoraggio/Valutazione, Politiche e pratiche scolastiche. 